\title{
Creative Workshop Based on Augmented Reality for the Strengthening of Creativity through the Learning of the Design Thinking Methodology ${ }^{\dagger}$
}

\author{
Cindy Hernández and Erika Duque * \\ Centro de Tecnologías para la Academia, Campus del Puente del Común, Universidad de La Sabana, Km. 7, \\ Autopista Norte de Bogotá, Chía, Colombia; Cindyhebe@unisabana.edu.co \\ * Correspondence: erika.duque@unisabana.edu.co; Tel.: +57-1-8615555 \\ + Presented at the 2nd Innovative and Creative Education and Teaching International Conference \\ (ICETIC2018), Badajoz, Spain, 20-22 June 2018.
}

Published: 30 October 2018

\begin{abstract}
This project aimed to analyze the influence of a learning environment mediated by augmented reality, implemented to strengthen the creative capacity for six students belonging to a technical educational institution in 2016, through the principles of the Design Thinking methodology. The research had a qualitative approach with a descriptive tendency within the design of a single case study. The learning environment included a series of activities congruent with the pedagogical proposals for creativity. In the implementation sessions the students were sensitized about the use of augmented reality and the creative process. The results show the improvement of the creative abilities of the participants in $87 \%$ of the creativity percentile according to the Torrence Test. The augmented reality contributed to the students being motivated in the process of exploratory design and curiosity and teamwork were fostered with a common goal.
\end{abstract}

Keywords: creativity; creative thinking; augmented reality; design thinking; learning environment; active learning

\section{Introduction}

The 21st century is called to be the century of creativity due to the demands to find new ideas and solutions to the problems of our society [1]. This research consisted of the design and implementation of a learning environment mediated by augmented reality and based on the Design Thinking methodology, whose objective was to analyze the influence of the learning environment to strengthen the creative capacity of six students belonging to a technical educational institution. The augmented reality allows the student to modify the real world at will without altering it, exploring the creative possibilities, since this technological mediation combines the real with the virtual taking advantage of the mobile devices that are already in the hands of the students [2]. The learning environment must take advantage of the ICT ecosystem that coexist with the school, and that has also changed since the massification of these devices. The learning environment included a series of activities congruent with the pedagogical proposals for the creativity of De Bono [3] and De la Torre [4]. Following the design process, the students assimilated their own cognitive and socio-affective environment to imagine contents through an experience in the classroom. The relevance of these initiatives is evident in the work of De la Torre and Violant, who affirm that societies that neglect and do not promote the development of creativity in young generations will face adverse conditions [5]. 


\section{Materials and Methods}

The participants were 6 high school students with ages between 15 and 18 years, who participated voluntarily and who were selected from the applied diagnostic test since they had the lowest scores in one or more of the categories to be evaluated. This research has a qualitative approach with a descriptive tendency. The assessment of the Torrance test was applied both in pretest and in a post-test to determine the strengthening of creative capacity. The categories of analysis were: Originality, which is the ability to produce ideas that are unusual; Fluidity, which is the ability to produce a large number of ideas; Flexibility, which is the ability to produce a wide variety of ideas and Elaboration, which is the ability to complete an idea. Another category of analysis was the access and management of augmented reality, in which it was intended to observe the behavior of students in the face of technological mediation, with three subcategories: motivation, access and management and learning through experience. The instruments for the collection of information were: participant observation, semi-structured interviews and evidence analysis.

\section{Results}

In the implementation sessions the students were sensitized about the use of augmented reality and the appropriation of the Design Thinking methodology, going through its stages, changing their attitudes and acquiring the mental skills proposed by Guilford as factors of divergent thinking [6]. Next, the activities carried out are explained:

- Activity 1: its objective was to increase the ability of students to produce new ideas for the development of fluency and flexibility. Emphasis was placed on the steps of Discovery and Interpretation of the Design Thinking methodology for students to understand the challenge from a fragment of the Alice in Wonderland chapter "Through the Looking Glass" and to gather all the information possible for the creation of six impossible ideas. QR codes were used as means of communication and discovery. In the development of the activity it was evidenced that two ideas emerged that are unusual and that together achieve the development of a graphic concept, demonstrating that the students fulfilled the originality parameters.

- Activity 2: contents were developed for the generation of ideas and the reinforcement of Fluency, Flexibility and Originality, breaking stereotyped and rigid thought patterns. Emphasis was placed on the steps of Discovery, Interpretation and Ideation of the Design Thinking methodology, since the aim was for the student to create an 'illogical animal' inspired by the Universal Animalario of Professor Revillod [7]. The use of QR codes during the activity had the metaphorical character to be the means of connection to the 'impossible world', making the twodimensional animal into a virtual three-dimensional element through the Chromeville application. This activity sought to encourage curiosity and therefore they were encouraged to take on other attitudes such as not being afraid of making mistakes, encouraging fantasy and seeking interaction with creative people, promoting diversity and individual thinking.

- Activity 3: contents were developed for the reinforcement of the Fluidity, Flexibility, Originality and Elaboration to apply the new ideas, emphasizing the steps of Empathy, Interpretation, Ideation and Experimentation of the Design thinking methodology, since it was sought that the student will elaborate the "illogical animal" by means of a 3D sculpture made with the materials of his preference, he should give a story to the sculpture, communicated by means of a third layer of information developed in augmented reality in Aurasma. In the resulting graphic productions, the gradual development of the variety and agility of functional thinking, the graphic and thought rapidity in unforeseen situations, the free creation and expression of the quantity of ideas were observed.

- Activity 4: aimed to interact with the environment, solving the problems and taking the appropriate decisions. It was developed within the framework of the immersive free-use workshop "An introduction to Design Thinking in one hour" [8] in which the participants completed the entire cycle of the design process. Snapchat was used to socialize the experience. In feedback they were asked about their perception of the use of augmented reality in their 
creative process and students gave equal importance to the use of augmented reality and the development of activities: the mediation of technology allowed to develop, design and propose ideas that otherwise would not have been possible. During the creative process it was emphasized that augmented reality is a means by which instructions are communicated to students and not an end in itself. Likewise, it was observed that the use of augmented reality applications as a means of communication appeared and was increasing in other fields of learning as progress was made in the development of activities.

As for the results of the Torrance test, a test was performed before and after the intervention, the results of which are shown below in Figure 1.

Taking into account the previous results, an index of figurative creativity obtained by adding the scores of the four components of the construct was calculated. The comparison of the values obtained for this index in the pre-test and in the post-test quantitatively demonstrates the impact of the process in terms of strengthening and the evolution of the figurative creativity of the students. The average figure for the change was $87 \%$.

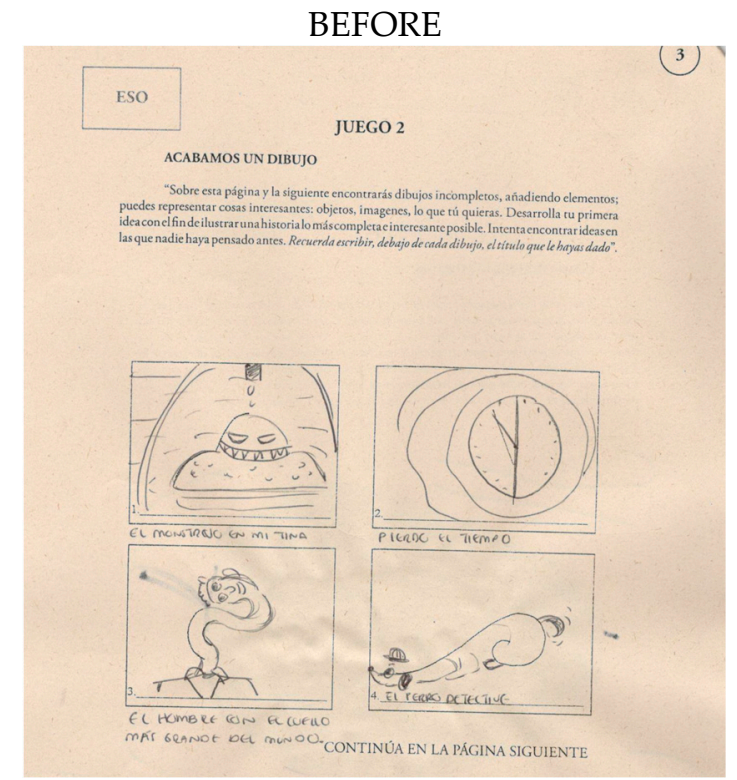

(a)

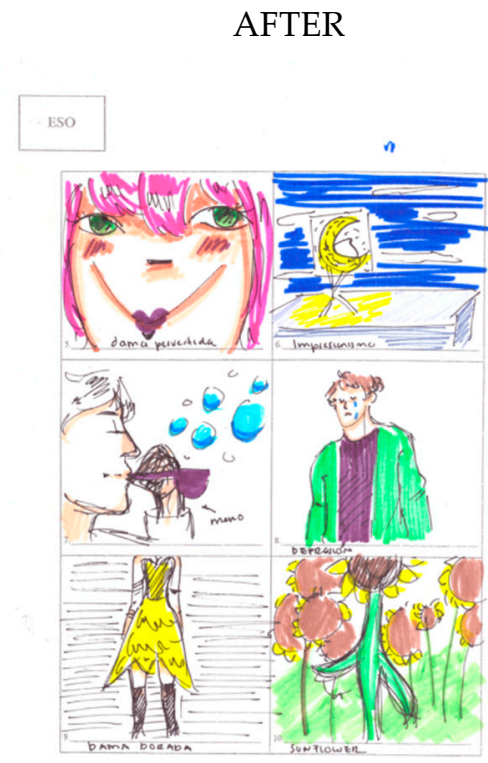

(b)

Figure 1. Student Pre Test and Post Test Results: (a) Student's results in the pre-test; (b) Student's post-test results.

\section{Conclusions}

For the Originality and Elaboration categories, a union of concepts and the creation of ideas from them was observed, elaboration at a detailed level both physical, graphic and conceptual, beautification of the idea with details or clarifications on the operation of the proposal $[9,10]$. Likewise, the increase of originality and the improvement of creative capacity were observed. The results show the improvement of the participants' creative abilities by $87 \%$ in the creativity percentile, according to the Torrence test. In conclusion, this experience shows the levels of attention, flexibility and adaptability in learning processes, increases the potential for innovation in a finite period of time. In addition, augmented reality contributed to students being motivated in the process of exploratory design [11] and curiosity and teamwork were fostered with a common goal.

Conflicts of Interest: The authors declare no conflict of interest. 


\section{References}

1. De la Torre, S. Comprender y Evaluar la Creatividad; Ediciones Aljibe: Málaga, España, 2006.

2. Reinoso, R. Realidad Aumentada: Posibilidades y usos en educación. In Recursos Educativos Aumentados: Una Oportunidad para la Inclusión; Baldiris, S.M., Duque, N.D., Salas, D.J., Bernal, J.C., Fabregat, R., Mendoza, R., Puerta, Y., Eds.; Sello Editorial Tecnológico Comfenalco: Cartagena de Indias, Colombia, 2016; pp. 8-25.

3. De Bono, E. El Pensamiento Creativo. El Poder del Pensamiento Lateral para la Creación de Nuevas Ideas; Paidós Empresa: Mexico, 1994.

4. De la Torre, S. Dialogando con la creatividad. In De la Identificación a la Creatividad Paradójica; Octaedro Ediciones: Barcelona, Spain, 2003.

5. De la Torre, S.; Violant, V. La Creatividad es Social. In Creatividad Aplicada; Promociones Publicaciones Universitarias: Barcelona, Spain, 2003. Available online: http://www.ub.edu/sentipensar/pdf/saturnino/ creatividad_social.pdf (accessed on 6 March 2017).

6. Stake, R.E. The Art of Case Study Research; Sage: Thousand Oaks, CA, USA, 1995.

7. Murugarren, M.; Saez, J. Animalario Universal del Profesor Revillod. Almanaque Ilustrado de la Fauna Mundial; Fondo de Cultura Económica: Mexico, 2003.

8. Plattner, H. Una Introducción al Design Thinking En Una Hora. 2012. Available online: https://dschoolold.stanford.edu/sandbox/groups/designresources/wiki/31fbd/attachments/08e2e/TheGiftGivingProjectB \%26W2012-Espa\%C3\%B1ol.pdf?sessionID=573efa71aea50503341224491c862e32f5edc0a9 (accessed on 11 April 2017).

9. Esquivias, M.T. Análisis del pensamiento creativo en estudiantes universitarios: Expresión lingüística. In Área 1: Aprendizaje y Desarrollo Humanos; Consejo Mexicano de Investigación Educativa, A.C.: Veracruz, Mexico, 2009. Available online: http://www.comie.org.mx/congreso/memoriaelectronica/v10/pdf/area_ tematica_01/ponencias/0639-F.pdf (accessed on 15 April 2017).

10. Jiménez González, J.E.; Artiles Hernández, C.; Rodríguez Rodríguez, C.; García Miranda, E. Adaptación y baremación del test de pensamiento creativo de Torrance: Expresión figurada. In Educación Primaria y Secundaria; Rodríguez, P.A., Ed.; Consejería de Educación, Cultura y Deportes del Gobierno de Canarias, Dirección General de Ordenación e Innovación Educativa: Canarias, Spain, 2007. Available online: http://creecyl.centros.educa.jcyl.es/sitio/upload/Libro_TORRANCE.pdf (accessed on 8 March 2017).

11. Baldiris, S.; Duque, N.; Salas, D.; Bernal, J.; Fabregat, R.; Mendoza, R.; Martinez, L. (Eds.). Recursos Educativos Aumentados: Una Oportunidad para la Inclusion; Sello Editorial Tecnológico Comfenalco: Cartagena de Indias, Colombia, 2016.

(C) 2018 by the authors. Licensee MDPI, Basel, Switzerland. This article is an open access article distributed under the terms and conditions of the Creative Commons Attribution (CC BY) license (http://creativecommons.org/licenses/by/4.0/). 